\title{
A rapid and sensitive liquid chromatography- tandem mass spectrometry method for the determination of amphetamine and related designer drugs in urine
}

\section{Une méthode par chromatographie liquide cou- plée à la spectrométrie de masse en tandem rapide et sensible pour le dosage de l'amphéta- mine et de drogues de synthèse dans les urines}

Charlotte MATTHYS ${ }^{(1)}$, Alain VERSTRAETE ${ }^{(1,2) *}$

(1) Department Clinical Chemistry and Toxicology, Ghent University Hospital - Belgium (2) Department of Clinical Biology, Microbiology and Immunology, Faculty of Medicine, Ghent University - Belgium

\footnotetext{
*Author for correspondence: Prof. Dr. Alain VERSTRAETE, Laboratory of Clinical Biology - Toxicology, Ghent University Hospital De Pintelaan 185 - B-9000 GENT BELGIUM Phone + 3292403407 - Fax + 3292404985 - E-mail : alain.verstraete@ugent.be
}

(Reçu le 10 janvier 2005 ; accepté après modifications le 7 avril 2005)

\section{SUMMARY}

A method for the direct analysis of six amphetamine compounds in urine was developed using liquid chromatography tandem mass spectrometry (LC-MS/MS). We added $90 \mu \mathrm{l}$ of a solution of internal standards $\left(1 \mu \mathrm{g} / \mathrm{mL}\right.$ of $d_{5}-A M P, d_{5^{-}}$ $M E T, d_{5}-M D A, d_{5}-M D M A, d_{5}-M D E A$ and $\left.d_{5}-M B D B\right)$ to $10 \mu l$ of urine followed by vortex-mixing and centrifugation. The sanple solutions were analyzed by LC-MS/MS in the MRM mode after separation on a reversed-phase C18 column using gradient elution. Separation and detection of all compounds was accomplished within eight minutes. Linearity was established for all compounds, from 78 to 100000 $\mathrm{ng} / \mathrm{mL}$. Correlation coefficients for all analytes exceeded 0.998 . The lower limit of quantification was $10 \mathrm{ng} / \mathrm{mLL}$ for all compourids, except for AMP and MDA (78 $\mathrm{ng} / \mathrm{mL})$. Withinday imprecision (CV\%) and between-day CVs (78,625 and

\begin{abstract}
$R \hat{E} S U M E ́$
Une méthode pour l'analyse directe de six amphétaniniques dans les urines a été développée en utilisant la chromatographie liquide couplée à la spectrométrie de masse en tandem (LC-MS/MS). Nous avons ajouté $90 \mu l$ d'un mélange d'étalons internes ( $1 \mu \mathrm{g} / \mathrm{mL}$ de $d_{5^{-}}$AMP, de $d_{5^{-}} M E T$, de $d_{5^{-}}$ $M D A$, de $d_{5}-M D M A$, de $d_{5}-M D E A$ et de $d_{5}-M B D B$ ) à $10 \mu l$ d'urine, mélangé par vortex et centrifugé. Les échantillons ont été analysés par LC-MS/MS en mode MRM après séparation sur une colonne $C 18$ à phase inverse en utilisant un. gradient d'élution. La séparation et la détection de tous les composés ont été accomplies en huit minutes. La linéarité a été établie pour tous les composés, de 78 à $100000 \mathrm{ng} / \mathrm{mL}$. Les coefficients de corrélation étaient supérieurs à 0.998. Les limites de quantification étaient. inférieures à $10 \mathrm{ng} / \mathrm{mL}$, sauf pour l'amphétanine et la $M D A(78 \mathrm{ng} / \mathrm{mL})$. La répéta-
\end{abstract}


$10000 \mathrm{ng} / \mathrm{mL}$ ) ranged from 2.62 to $16.26 \%$ and from 0.86 to $11.98 \%$, respectively. Accuracy (bias\%) lay between 0.16 and $7.17 \%$. The peak areas of the amphetamines added to urine fell in the range 85-115\% compared to standard solutions in methanol/water; except for AMP and MDA. Carryover was negligible and stability after storage at room temperature for up to $24 \mathrm{~h}$ was acceptable. In conclusion, the presented method allows the accurate, precise and rapid determination of six anphetamine compounds in urine over a wide analytical range.

\section{KEY-WORDS}

Amphetamines, MDMA, liquid chromatography, tandem mass spectrometry, urine.

\section{Introduction}

In the last few decades, amphetamine designer drugs have gained popularity as recreational drugs and they are used mainly for their stimulating effects, especially in gatherings known as raves and in the dancing scene $(1,2)$. Monitoring of amphetamines and designer drugs in human urine is successfully used for clinical and forensic applications.

For most clinical and forensic applications, initial screening is performed by an immunoassay, and presumptive positive samples are confirmed by a more specific method. To date, the confirmation of amphetamines in urine samples is mainly performed by gas chromatography-mass spectrometry (GC-MS)(3). Despite the many advantages of GC-MS, such as the high sensitivity and specificity and its widespread availability, it does have limitations. One of them, linked to amphetamines, is that the compounds with the amphetamine core structure have base peaks at low masses, resulting in interference from biological background. This can be overcome by the use of extraction from the biological fluid, followed by derivatisation, a step also needed for improving the GC-properties of the compounds. A major drawback of derivatisation, specifically in a routine laboratory with a large number of samples to be analysed in a short time, is that the procedure becomes laborious and time-consuming.

Headspace solid phase micro-extraction (SPME) is one potential solution to minimize the time spent by technical staff preparing samples for GC-MS analysis (4). The disadvantages, on the other hand, are the need for special equipment, the carry-over effect and the need for conditioning of the fibre before use. These limitations of GC-MS led to investigate alternative approaches for analysing amphetamines in biological fluids. bilité $(C V \%)$ et la reproductibilité variaient respectivement entre 2.62 et $16.26 \%$ et entre 0.86 et $11.98 \%$. En ce qui concerne l'exactitude, le pourcentage de biais à 78 et 10000 $n g / m L$ variait entre 0.16 et $7.17 \%$. La surface des pics des amphétamines ajoutées à de l'urine variait entre 85 et 100\% de celle des amphétamines dissous dans un mélange d'eau et de méthanol, excepté pour l'amphétanine et le MDA. Le carry-over était négligeable et la stabilité (156 et $5000 \mathrm{ng} / \mathrm{mL}$ ) après stockage à la température annbiante pendant 24 he était acceptable. En conclusion, la méthode présentée permet la détermination exacte, précise et rapide de six amphétaminiques dans les urines sur une plage de concentration large.

\section{MOTS-CLÉS}

Amphétamines, MDMA, chromatographie en phase liquide, spectrométrie de masse en tandem, urine.

In the last few years, liquid chromatography coupled to mass spectrometry (LC-MS) has developed rapidly in forensic and clinical applications $(5,6)$. Several LC-MS interface types are described. Today, however, two relatively robust LC-MS interface types are most frequently used, the atmospheric-pressure ionisation techniques, electrospray (ESI) and atmospheric-pressure chemical ionisation (APCI). LC-MS offers a higher sensitivity and specificity and reduces sample preparation required with GC-MS because relatively non-volatile compounds can be analysed and no derivatisation is necessary.

A further development is the combination of two mass spectrometers with an interposed collision cell. This characterizes LC-tandem mass spectrometry (LCMS/MS), which generally provides superior limit of quantification (LOQ), sensitivity and improved selectivity. An extra advantage of MS-MS, in respect of MS, is the ability to shorten the chromatographic run-time dramatically.

This paper describes the validation of a liquid chromatography-APCI-tandem mass spectrometry method (LC-APCI-MS/MS) for simultaneous analysis of six amphetamine compounds in urine. This method is based on the method of Nordgren et al.(7).

\section{Materials and Methods}

\section{Chemicals and reagents}

Standard solutions of amphetamine (1 $\mathrm{mg} / \mathrm{mL})$, methamphetamine $(1 \mathrm{mg} / \mathrm{mL}), 3,4$-methylenedioxyamphetamine (MDA) (1 mg/mL), 3,4- methylenedioxymethamphetamine (MDMA) (1 mg/mL), 3,4-methylenedioxyethylamphetamine (MDEA) (1 mg/mL), Nmethyl-1-(3,4-methylenedioxyphenyl)-2-butanamine $(\mathrm{MBDB})(1 \mathrm{mg} / \mathrm{mL})$, and $d_{5}$-deuterated analogues $(100$ 
$\mu \mathrm{g} / \mathrm{mL}$ ) used as internal standards (IS) in methanol were obtained from Cerilliant (Austin, Texas). Methanol (absolute) and water for LC-MS were purchased from Biosolve (Valkenswaard, The Netherlands). Ammonium acetate (p.a) was supplied by Sigma-Aldrich (Bornem, Belgium).

\section{Instrumentation and MS/MS conditions}

An Agilent 1100 series HPLC system (Agilent Technologies) consisting of a pump, column oven, autosampler and degasser were used for solvent delivery and sample introduction. The injected volume was $20 \mu \mathrm{l}$. Analytes were separated at $40^{\circ} \mathrm{C}$ on a $2.1 \times 30$ mm Zorbax SB-C18. Rapid Solution column (Agilent Technologies). The column was eluted at a flow rate of $0.3 \mathrm{~mL} / \mathrm{min}$ and developed with gradient elution as follows: $0-0.2 \mathrm{~min}, 95 \% \mathrm{~A} / 5 \% \mathrm{~B} ; 1.2-4.5 \mathrm{~min}, 5 \% \mathrm{~A} / 95 \% \mathrm{~B}$ and 4.8-8 $\mathrm{min} 95 \% \mathrm{~A} / 5 \% \mathrm{~B}\left(\mathrm{~A}: \mathrm{H}_{2} \mathrm{O}+2 \mathrm{mM}\right.$ ammoniumacetate, $\mathrm{B}: \mathrm{MeOH}+2 \mathrm{mM}$ ammoniumacetate).

The LC-MS/MS system consisted of an API $2000^{\mathrm{TM}}$ triple-quadrupole mass spectrometer equipped with an APCI interface (Applied Biosystems/MDS Sciex, Langen, Germany) used in the positive-ion mode. The six amphetamine compounds were detected in the multiple-reaction monitoring mode. Two MRM transitions for each substance were monitored to provide sufficient identification of the amphetamine compounds. The chosen MRM transitions for each amphetamine compound and $d_{5}$-deuterated analogue are summarised in table 1 . The entrance potential varied from $5.5 \mathrm{~V}$ to

Table I : Retention time, parent ion and the chosen daughter ions for each amphetamine compound and $\mathrm{d}_{5}$-deuterated analogue

\begin{tabular}{|c|c|c|c|c|}
\hline A mphétamines & $\begin{array}{c}\text { Retention } \\
\text { lime (min) }\end{array}$ & M+1 & MRM 1 & MRM 2 \\
\hline AMP & 4.20 & 136.079 & 91.05 & 65.05 \\
\hline MET & 4.36 & 150.078 & 91.05 & 119.15 \\
\hline MDA & 4.29 & 180.119 & 135.15 & 133.05 \\
\hline MDMA & 4.38 & 194.085 & 163.05 & 105.05 \\
\hline MDEA & 4.50 & 208.068 & 163.05 & 105.15 \\
\hline MBDB & 4.61 & 208.068 & 135.05 & 177.15 \\
\hline$d_{5}$-AMP & 4.17 & 141.112 & 93.35 & \\
\hline$d_{5}$-MET & 4.35 & 155.09 & 92.35 & \\
\hline$d_{5}-$ MDA & 4.26 & 185.114 & 110.15 & \\
\hline$d_{5}-$ MDMA & 4.35 & 199.136 & 165.15 & \\
\hline$d_{5}$-MDEA & 4.48 & 213.075 & 163.05 & \\
\hline$d_{5}-$ MBDB & 4.60 & 199.136 & 165.15 & \\
\hline
\end{tabular}

$9 \mathrm{~V}$, the collision cell entrance potential varied from 14 to $20 \mathrm{~V}$ and the cell exit potential was set at $2 \mathrm{~V}$ or $4 \mathrm{~V}$, according to the analyte.

Analyst Software (Ver. 1.3.1; Applied Biosystems/MDS Sciex) was used for HPLC system control, data acquisition, and data processing.

\section{Calibration standards and internal stan- dard mix-solution}

Calibration standards were prepared in drug-free urine from methanolic stock solutions, containing all amphetamine compounds at a concentration of $1 \mathrm{mg} / \mathrm{mL}$. The concentrations of the calibration standards were $78.125,156.25,312.5,625,1250,5000,10000,20000$, $30000,40000,50000,60000,70000,80000,90000$ and $100000 \mathrm{ng} / \mathrm{mL}$.

For recovery testing, standards with concentrations of $78.125,625$ and $10000 \mathrm{ng} / \mathrm{mL}$ were made in $\mathrm{H}_{2} \mathrm{O} / \mathrm{MeOH}(50 / 50)$ solution from the same stock solutions $(1 \mathrm{mg} / \mathrm{mL})$.

The internal standard-mix solution $(1 \mu \mathrm{g} / \mathrm{mL}$ of each amphetamine) was prepared by dilution of $10 \mu \mathrm{l}$ from each $d_{5}$-deuterated analogue in $10 \mathrm{~mL}$ distilled water.

All standards were stored at $4^{\circ} \mathrm{C}$ and were allowed to come to room temperature, vortex-mixed and centrifuged prior to analysis.

\section{Sample preparation}

Sample preparation was minimal and consisted of adding $90 \mu \mathrm{l}$ of the internal standard-mix solution to 10 $\mu \mathrm{l}$ of sample (calibration standards and standards made in $\mathrm{H}_{2} \mathrm{O} / \mathrm{MeOH}(50 / 50)$ solution). After vortex-mixing and centrifugation $(2 \mathrm{~min}$ at $13000 \mathrm{~g}$ ), $85 \mu \mathrm{l}$ of the sample solution was pipetted into crimp-cap autosampler vials and placed in the autosampler.

\section{Validation experiment}

Method validation, including studies of imprecision (within-day and between-day), accuracy, linearity, stability, carry-over, recovery and the determination of the limit of detection (LOD) and quantification (LOQ) of the LC-MS/MS method was performed according to the FDA recommendations (8).

\section{Results and discussion}

Figure I shows a typical LC-MS/MS chromatogram of a patient urine sample containing $11400 \mathrm{ng} / \mathrm{mL}$ AMP, $5633 \mathrm{ng} / \mathrm{mL}$ MDMA and $281 \mathrm{ng} / \mathrm{mL}$ MDA. 


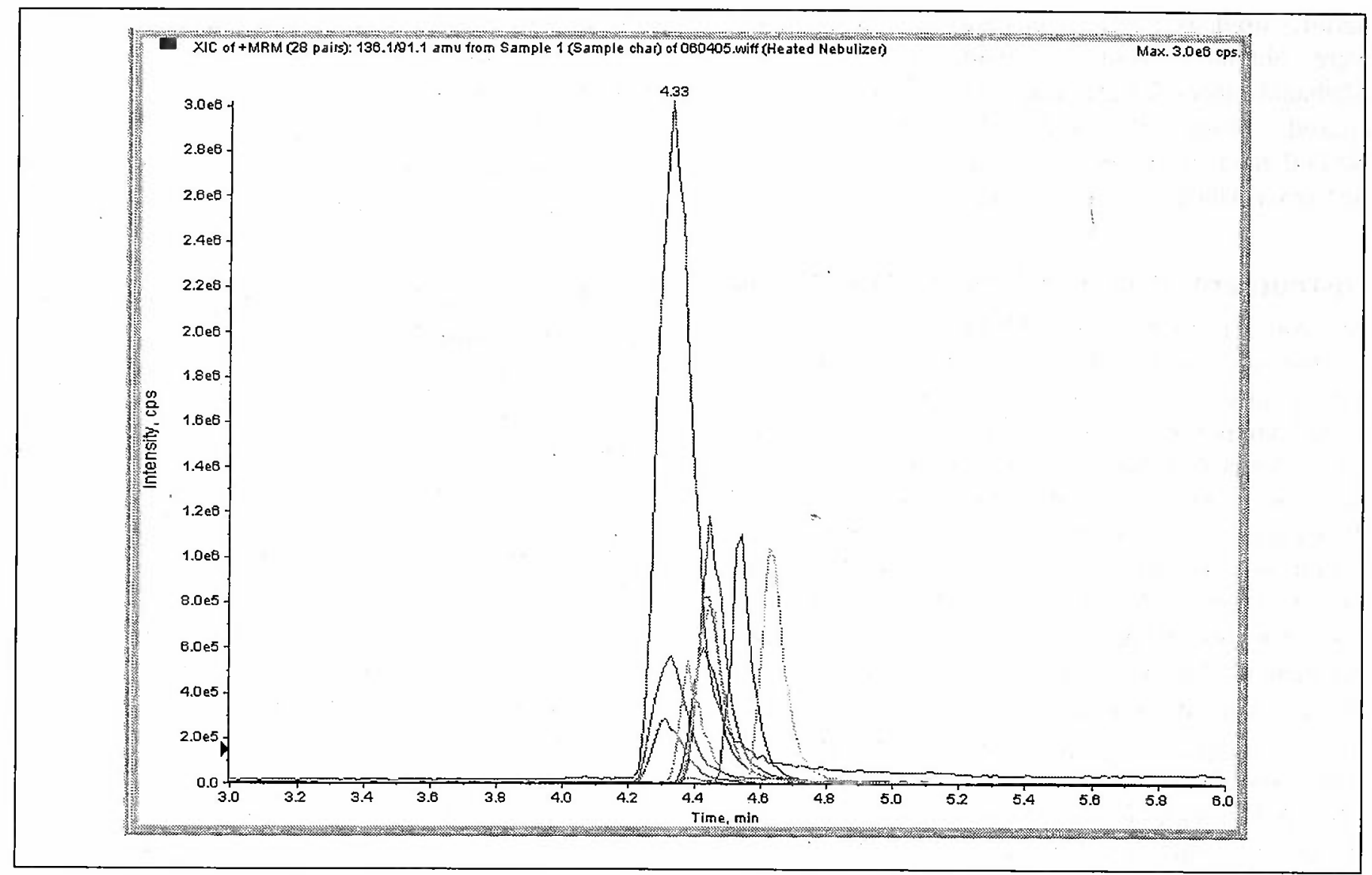

Figure 1 : LC-MS/MS chromatogram of a patient urine sample containing AMP (11400 ng/mL), MDMA (5633 ng/mL) and MDA $(281 \mathrm{ng} / \mathrm{mL})$. The retention times $(R T)$ of the internal standards are $4.33 \mathrm{~min}\left(d_{5}-A M P\right), 4.43 \mathrm{~min}\left(d_{5}-M E T\right), 4.38 \mathrm{~min}\left(d_{5}-M D A\right)$, $4.43 \min \left(d_{5}-M D M A\right), 4.54 \min \left(d_{5}-M D E A\right)$, and $4.63 \min \left(d_{5}-M B D B\right)$.

\section{Calibration curves}

To construct calibration curves, a set of eight urine samples spiked with the amphetamine compounds at concentrations ranging from $78 \mathrm{ng} / \mathrm{mL}$ to $10000 \mathrm{ng} / \mathrm{mL}$ were used. The calibrators were measured for five consecutive days. All calibration curves showed linearity for all amphetamine compounds and correlation coefficients exceeded 0,998 .

\section{LOD and LOQ}

The limit of detection (LOD), defined as a signal-tonoise ratio of 3 , and the limit of quantification (LOQ), defined as a signal-to-noise ratio of 10 , were calculated by a script in the Analyst Software. The LOD and LOQ were $4.9 \mathrm{ng} / \mathrm{mL}$ and $9.8 \mathrm{ng} / \mathrm{mL}$, respectively for each analyte except for amphetamine and MDA (table II). The LOQ's are lower than the current recommended urine confirmation cut-off levels (9). However if for certain applications higher sensitivity is necessary some modifications can be tried out: increasing the injected volume, increasing the sample/internal standard ratio, lowering the number of MRM-transitions or another procedure (e.g. with extraction) can be applied.
Table II : Limit of detection and limit of quantification for each amphetamine compound.

\begin{tabular}{|c|c|c|}
\hline Amphétamines & LOD $(\mathbf{n g} / \mathrm{mL})$ & LOQ $(\mathrm{ng} / \mathrm{mL})$ \\
\hline AMP & 39.1 & 78.1 \\
\hline MET & 4.9 & 9.8 \\
\hline MDA & 39.1 & 78.1 \\
\hline MDMA & 4.9 & 9.8 \\
\hline MDEA & 4.9 & 9.8 \\
\hline MBDB & 4.9 & 9.8 \\
\hline
\end{tabular}

\section{Imprecision}

Imprecision (CV\%) was evaluated by analysing three calibrator samples with a low $(78 \mathrm{ng} / \mathrm{mL})$, medium $(625 \mathrm{ng} / \mathrm{mL})$ and high $(10000 \mathrm{ng} / \mathrm{mL})$ concentration of each amphetamine on the same day in five replicates (within-day imprecision) and over five consecutive days (between-day reproducibility). The within-day CVs ranged from 2.62 to $16.26 \%$, the between-day CVs from 0.86 to $11.98 \%$ (table III). So, data for imprecision were within required limits of $20 \%$ at the 
Tableau III : Imprecision (CV\%), bias (\%) and recovery (\%) determined for three calibration standards with low' (78 ng/mL) medium $(625 \mathrm{ng} / \mathrm{mL})$ and high $(10000 \mathrm{ng} / \mathrm{mL})$ concentration of each amphetamine compound, respectively ( $\mathrm{n}=5)$.

\begin{tabular}{|c|c|c|c|c|c|c|c|c|c|c|c|c|}
\hline & \multicolumn{6}{|c|}{ Imprecision (CV \%) } & \multirow{2}{*}{\multicolumn{3}{|c|}{ Accuracy (bias\%) }} & \multirow{2}{*}{\multicolumn{3}{|c|}{ Recovery (\%) }} \\
\hline & \multicolumn{3}{|c|}{ Within-day CV } & \multicolumn{3}{|c|}{ Between-day CV } & & & & & & \\
\hline & $\begin{array}{c}78 \\
\mathrm{ng} / \mathrm{mL} \\
\end{array}$ & $\begin{array}{c}625 \\
\mathrm{ng} / \mathrm{mL} \\
\end{array}$ & $\begin{array}{l}10000 \\
\mathrm{ng} / \mathrm{mL}\end{array}$ & $\begin{array}{c}78 \\
\mathrm{ng} / \mathrm{mL}\end{array}$ & $\begin{array}{c}625 \\
\mathrm{ng} / \mathrm{mL} \\
\end{array}$ & $\begin{array}{l}10000 \\
\mathrm{ng} / \mathrm{mL}\end{array}$ & $\begin{array}{c}78 \\
\mathrm{ng} / \mathrm{mL} \\
\end{array}$ & $\begin{array}{c}625 \\
\mathrm{ng} / \mathrm{mL} \\
\end{array}$ & $\begin{array}{l}10000 \\
\mathrm{ng} / \mathrm{mL}\end{array}$ & $\begin{array}{c}78 \\
\mathrm{ng} / \mathrm{mL}\end{array}$ & $\begin{array}{c}625 \\
\mathrm{ng} / \mathrm{mL} \\
\end{array}$ & $\begin{array}{l}10000 \\
\mathrm{ng} / \mathrm{mL}\end{array}$ \\
\hline AMP & 16.26 & 4.76 & 3.86 & 7.07 & 4.39 & 0.86 & 2.5 & 1.0 & 1.6 & 61 & 78 & 70 \\
\hline MET & 3.39 & 2.94 & 3.35 & 3.83 & 4.14 & 1.29 & 2.4 & 0.5 & 2.4 & 110 & 109 & 99 \\
\hline MDA & 3.42 & 4.60 & 3.41 & 10.42 & 3.05 & 1.89 & 7.7 & 1.3 & 0.2 & 94 & 93 & 75 \\
\hline MDMA & 6.80 & 2.77 & 4.42 & 11.98 & 3.57 & 1.61 & 4.1 & 0.2 & 1.4 & 108 & 108 & 95 \\
\hline MDEA & 8.17 & 3.53 & 5.36 & 10.98 & 3.91 & 1.29 & 3.0 & 0.2 & 0.8 & 101 & 102 & 92 \\
\hline $\mathrm{MBDB}$ & 10.76 & 5.68 & 2.62 & 2.40 & 2.39 & 2.20 & 1.1 & 3.4 & 0.4 & 102 & 105 & 98 \\
\hline
\end{tabular}

lowest concentration and below $15 \%$ at higher concentrations.

\section{Accuracy}

The accuracy of this method for each amphetamine compound was obtained by analyzing the same three calibration standards as mentioned in the paragraph 'imprecision' over five consecutive days. As indicated in table III, the calculated concentration of each compound agreed well with the expected values.

\section{Recovery}

The recoveries were obtained by comparing the peak areas of spiked urine with those of the same concentrations of the analytes in $\mathrm{H}_{2} \mathrm{O} / \mathrm{MeOH}(50 / 50)$ solution. Three concentrations were tested $(78 \mathrm{ng} / \mathrm{mL} ; 625$ $\mathrm{ng} / \mathrm{mL} ; 10000 \mathrm{ng} / \mathrm{mL}$ ) in five-fold. The results are presented in table III. We observed good agreement ( $<15 \%$ deviation) for most analytes, except for amphetamine (all concentrations) and MDA (only the highest concentration).

\section{Carry-over}

Carry-over was evaluated by injecting a blank urine specimen containing the internal standards immediately after a sample that contained $10000 \mathrm{ng} / \mathrm{mL}$ of each amphetamine compound. Carry-over was less than $0.32 \%$ and the results are shown in table IV. Although the carry-over is low, the confirmation cut-off of 200 $\mathrm{ng} / \mathrm{mL}$ could be reached after a sample containing $60000 \mathrm{ng} / \mathrm{mL}$ of an amphetamine, which occurs occasionally.
Table IV : Carry-over (\%) in a blank urine sample analyzed after a calibration standard with a concentration of 10000 $n g / m L$

\begin{tabular}{|c|c|}
\hline Amphétamines & Carry-over (\%) \\
\hline AMP & 0 \\
\hline MET & 0.22 \\
\hline MDA & 0.06 \\
\hline MDMA & 0.22 \\
\hline MDEA & 0.32 \\
\hline MBDB & 0.26 \\
\hline
\end{tabular}

\section{Linearity above $10000 \mathrm{ng} / \mathrm{mL}$}

Standards with concentrations between $20000 \mathrm{ng} / \mathrm{mL}$ and $100000 \mathrm{ng} / \mathrm{mL}$, made in drug-free urine samples, were used to determine linearity above $10000 \mathrm{ng} / \mathrm{mL}$. The linearity was evaluated by dividing the observed value of each standard by the expected value of each standard to determine the percentage of the expected result for each concentration. The percentages of the expected results for the amphetamines were between $91 \%$ and $107 \%$ (table V).

\section{Stability}

For stability studies, two calibration standards (calibration standard 2 with a concentration of $156 \mathrm{ng} / \mathrm{mL}$ and calibrator 7 with a concentration of $5000 \mathrm{ng} / \mathrm{mL}$ ) were each split into 10 aliquots, with five aliquots assayed immediately and the other five stored for up to $24 \mathrm{~h}$ at room temperature. The means of the five determinations for each calibrator, before and after storage were then compared. The data are given in table VI. 
Tableau $V$ : Linearity obtained by dividing the observed value of each standard by the expected value of each standard and multiplied by 100 . The deviations (\%) were below $10 \%$.

\begin{tabular}{|c|c|c|c|c|c|c|c|c|c|}
\hline \multirow{2}{*}{ Amphetamine } & \multicolumn{7}{|c|}{ Lizearity as deviation (\%) of the observed value to the expected value } \\
\cline { 2 - 12 } & $\begin{array}{c}20000 \\
\mathrm{ng} / \mathrm{mL}\end{array}$ & $\begin{array}{c}30000 \\
\mathrm{ng} / \mathrm{mL}\end{array}$ & $\begin{array}{c}40000 \\
\mathrm{ng} / \mathrm{mol}\end{array}$ & $\begin{array}{c}50000 \\
\mathrm{ng} / \mathrm{mal}\end{array}$ & $\begin{array}{c}60000 \\
\mathrm{ng} / \mathrm{mL}\end{array}$ & $\begin{array}{c}70000 \\
\mathrm{ng} / \mathrm{mL}\end{array}$ & $\begin{array}{c}80000 \\
\mathrm{ng} / \mathrm{mL}\end{array}$ & $\begin{array}{c}90000 \\
\mathrm{ng} / \mathrm{mL}\end{array}$ & $\begin{array}{c}100000 \\
\mathrm{ng} / \mathrm{mL}\end{array}$ \\
\hline AMP & 107 & 104 & 103 & 103 & 101 & 98,7 & 101 & 97,2 & 92,3 \\
\hline MET & 107 & 106 & 104 & 106 & 104 & 100 & 100 & 97.4 & 95.4 \\
\hline MDA & 91.8 & 95 & 96 & 103 & 102 & 104 & 105 & 104 & 97.4 \\
\hline MDMA & 104 & 106 & 103 & 106 & 99.7 & 102 & 102 & 100 & 94 \\
\hline MDEA & 109 & 101 & 106 & 107 & 99.1 & 101 & 99.7 & 100 & 94.8 \\
\hline MBDB & 107 & 105 & 99.2 & 104 & 104 & 101 & 102 & 102 & 92.7 \\
\hline
\end{tabular}

Table VI : Stability of two calibration standards with a concentration of $156 \mathrm{ng} / \mathrm{mL}$ and $5000 \mathrm{ng} / \mathrm{mL}$, respectively after a 24 h storage at room temperature. The means of five determinations for each compound, before and after storage were subtracted and divided by the mean of the corresponding results obtained before storage.

\begin{tabular}{|c|c|c|}
\hline Amphétamine & \multicolumn{2}{|c|}{ Stahility (\%) } \\
& $156 \mathrm{ag} / \mathrm{mL}$ & $5000 \mathrm{ng} / \mathrm{mL}$ \\
\hline AMP & 6.8 & -1.78 \\
\hline MET & 1.43 & -0.26 \\
\hline MDA & -3.31 & -14.66 \\
\hline MDMA & -3.45 & 0.07 \\
\hline MDEA & -11.99 & -5.04 \\
\hline MBDB & -15.87 & -13.57 \\
\hline
\end{tabular}

\section{Conclusion}

We have developed and validated a LC-MS/MS method for the simultaneous determination of six amphetamine compounds in urine samples. The sample pre-treatment is fast and simple, requiring no derivatisation. The LOQs are much lower than recommended urine confirmation cut-off levels, i.e. this method is sensitive enough for routine confirmation. Accuracy and imprecision fulfil the criteria of $<20 \%$ at a concentration equal to the LOQ and $<15 \%$ at higher concentrations. Good recoveries and linearity over a wide analytical range were obtained. Carry-over is minimal. Separation and detection of all compounds was accomplished within eight minutes. The main advantages of the present method lie in its simple sample preparation, reliable results and short analysis time.

\section{Acknowledgments}

We thank Fien Vander Heyden for assistance during the development of this method.

\section{Références}

1. European Monitoring centre for drugs and drug addiction. Annual report 2004: the state of the drugs problem in the European Union and Norway. Luxembourg: Bureau for the official publications of the European Union, 2004 ; 1-113.

2. United nations office on drugs and crime. 2004 World Drug report. United Nations. Geneva: United Nations Publications, 2004 ; 1-427.

3. Kraemer T., Maurer H.H. Determination of amphetamine, methamphetamine and amphetamine-derived designer drugs or medicaments in blood and urine. $\mathrm{J}$. Chromatogr. B Biomed. Sci. Appl. 1998 ; 713 : 163-87.

4. Jurado C., Gimenez M.P., Soriano T., Menendez M., Repetto M. Rapid analysis of amphetamine, methamphetamine, MDA, and MDMA in urine using solid-phase microextraction, direct on-fiber derivatization, and analysis by GC-MS. J. Anal. Toxicol. $2000 ; 24$ : 11-6.

5. Marquet $P$. Progress of liquid chromatography-mass spectrometry in clinical and forensic toxicology. Ther. Drug Monit. 2002 ; 24 : 255-76.

6. Marquet P., Lachatre G. Liquid chromatography-mass spectrometry: potential in forensic and clinical toxicology. J. Chromatogr. B Biomed. Sci. Appl. 1999 ; 733 : 93118.

7. Nordgren H.K., Beck O. Direct screening of urine for MDMA and MDA by liquid chromatography-tandem mass spectrometry. J. Anal. Toxicol. $2003 ; 27: 15-9$.

8. US Department of Health and Human Services Food and Drug Administration - Center for Drug Evaluation and Research (CDER). Guidance for Industry, Bioanalytical Method Validation. $2001 ; 1-25$

9. Substance abuse and mental health services administration Proposed revisions to mandatory guidelines for federal workplace drug testing programs. Federal Register $2004 ; 69$ : 19673-732. 